JAMP: Jurnal Adminitrasi dan Manajemen Pendidikan

Volume 1 Nomor 3 September 2018, Hal : 372-380

Tersedia Online di http://journal2.um.ac.id/index.php/jamp/

ISSN 2615-8574 (online)

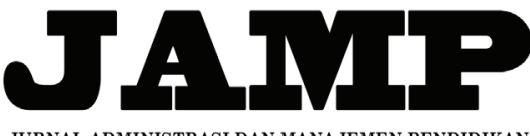

JURNAL ADMINISTRASI DAN MANAJEMEN PENDIDIKAN

\title{
MANAJEMEN KURIKULUM TERPADU DI SEKOLAH ALAM BERCIRI KHAS ISLAM
}

\author{
Zoga Adipratama \\ Raden Bambang Sumarsono \\ Nurul Ulfatin \\ zogaadipratama@gmail.com \\ Universitas Negeri Malang, Jl. Semarang No. 5 Malang 65145
}

\begin{abstract}
The purpose of this research is to find out about the implementation of school curriculum management nature. characteristic of Islam. This research uses qualitative descriptive method with this type of case studies. A data source includes the principal researchers, teachers, students and representatives of the principal part of the curriculum. Data collection techniques in the form of interviews, observation, documentation. Data analysis was conducted concurrently with data collection in the field with the analysis process consists of a reduction of data, display data, and verify the data. The results of this research are (1) planning curriculum through workshops to prepare learning devices for one academic year, (2) the preparation of the school calendar is done after receiving a calendar of national education, (3) preparing the progam work performed each end of the new school year and the school do the evaluation at the end of each year to determine the new work program next, (4) preparation of the schedule of lessons arranged by vice principal part of the curriculum and its curriculum with the team see the urgency subjects of competence which are then invited to the head of school, (5) the Division of the burden of teaching based on the number of teachers and the number of teaching hours of teachers, (6) implementation of teaching and learning program conducted after the teacher and the learners perform prayers Duha, reading and memorizing the Qur'an, (7) evaluation of the integrated curriculum is carried out each week on Friday to figure out the constraints and how to solve the constraints directly.
\end{abstract}

Keywords: management,integrated curriculum, school of natural characteristic of Islam

\begin{abstract}
Abstrak: Tujuan penelitian ini adalah untuk mengetahui tentang pelaksanaan manajemen kurikulum sekolah alam.berciri khas Islam. Penelitian ini menggunakan metode deskriptif kualitatif dengan jenis studi kasus. Sumber data peneliti meliputi kepala sekolah, guru, siswa dan wakil kepala sekolah bagian kurikulum. Teknik pengumpulan data berupa wawancara, observasi, dokumentasi. Analisis data dilakukan bersamaan dengan pengumpulan data di lapangan dengan proses analisis terdiri dari reduksi data, display data, dan verifikasi data. Hasil penelitian ini (1) perencanaan kurikulum melalui kegiatan workshop untuk mempersiapkan perangkat pembelajaran selama satu tahun ajaran, (2) penyusunan kalender sekolah dilakukan setelah mendapat kalender pendidikan nasional, (3) penyusunan progam kerja dilakukan setiap akhir tahun ajaran baru dan sekolah melakukan evaluasi di setiap akhir tahun untuk menentukan progam kerja baru selanjutnya, (4) penyusunan jadwal pelajaran disusun oleh wakil kepala sekolah bagian kurikulum beserta tim kurikulum dengan melihat urgensi kompetensi mata pelajaran yang kemudian dikonsultasikan kepada kepala sekolah, (5) pembagian beban mengajar berdasarkan pada banyaknya guru dan jumlah jam mengajar guru, (6) pelaksanaan progam belajar mengajar dilakukan setelah guru dan peserta didik melakukan kegiatan sholat dhuha, membaca serta menghafal Al-Qur'an, (7) evaluasi kurikulum terpadu dilakukan setiap satu minggu di hari jum'at untuk mengetahui kendala dan cara menyelesaikan kendala tersebut secara langsung.
\end{abstract}

Kata kunci: manajemen, kurikulum terpadu, sekolah alam berciri khas Islam 
Sekolah sebagai lembaga pendidikan dirancang khusus untuk pengajaran siswa dibawah pengawasan guru. Pendidikan tidak hanya fokus pada mutu dan kualitas guru sebagai tenaga pendidik dalam mencetak lulusan, tetapi juga harus mempertimbangkan aspek lain. Pada setiap lembaga pendidikan selalu terdapat tim yang menangani urusan kurikulum. Menurut Hamalik (dalam putri 2010:12) "Salah satu aktivitas terpenting manajemen kurikulum di lembaga pendidikan adalah mengelola pembelajaran".

Setiap satuan pendidikan memiliki kurikulum untuk menjadi dasar dalam mencapai tujuan yang diinginkan oleh satuan pendidikan tersebut. Kurikulum adalah suatu bagian dalam pendidikan yang berfungsi untuk mewujudkan hal yang menjadi tujuan dari pendidikan nasional. Hal tersebut yang mendasari pemerintah untuk selalu memperbaharui kurikulum agar mendapatkan kurikulum yang ideal, karena dengan kurikulum yang tepat dan ideal diharapkan akan mampu menciptakan sumberdaya manusia yang unggul dan berkualitas. Menurut Slameto (2003:16) "Keberhasilan progam pendidikan dalam proses belajar mengajar sangat dipengaruhi oleh beberapa faktor yaitu siswa, kurikulum, tenaga kependidikan, dana, sarana dan prasarana, serta faktor lingkungan lainnya'. Apabila semua faktor tersebut terpenuhi, maka akan menghasilkan peningkatan mutu pendidikan di Indonesia.

SMA Surya Buana merupakan salah satu sekolah swasta di Malang, yang berdiri di bawah naungan Yayasan Bahana Cita Persada Malang. Kurikulum yang digunakan di SMA Surya Buana Malang merupakan sistem kurikulum terpadu yaitu perpaduan antara kurikulum yang diterapkan oleh Dinas Pendidikan Nasional (Diknas) dan kurikulum khusus sekolah yang berciri khas Islam. Kurikulum nasional yang ada di SMA Surya Buana Malang adalah kurikulum 2013. Sedangkan kurikulum khusus sekolah menerapkan hidden curriculum yaitu kurikulum khas SMA Surya Buana yang sudah disesuaikan dengan lingkungan dan kondisi sekolah yang berciri khas Islam. Hal ini sesuai dengan hasil penelitian Ainurrosidah (2018:164) menyatakan kurikulum terpadu adalah" perpaduan kurikulum yang ditetapkan oleh dinas pendidikan nasional, dan kurikulum yang menjadi ciri khas dari sekolah".

Menurut Undang-Undang Nomor 20 Tahun 2003 tentang Sistem Pendidikan Nasional kurikulum adalah "seperangkat rencana dan pengaturan mengenai tujuan, isi dan bahan pelajaran serta cara yang digunakan sebagai pedoman penyelenggaraan kegiatan pembelajaran untuk mencapai tujuan pendidikan tertentu". Sedangkan menurut Dakir (2004:3) kurikulum adalah "suatu progam yang berisikan berbagai bahan ajar dan pengalaman belajar yang diprogamkan, direncanakan dan dirancangkan secara sistematik dalam proses pembelajaran bagi tenaga kependidikan dan peserta didik untuk mencapai tujuan pendidikan". Jadi dapat disimpulkan bahwa kurikulum adalah seperangkat rencana dan pengaturan yang berupa mata pelajaran dan progam pendidikan yang diberikan oleh suatu lembaga pendidikan yang dirancang secara sistematis untuk mencapai tujuan pendidikan. Manajemen kurikulum adalah proses penggunaan semua sumber daya yang bertujuan untuk menyelenggarakan pembelajaran dan progam pendidikan dengan melalui tahapan-tahapan yang dimulai dari perencanaan, pengorganisasian, pengawasan sampai dengan tahap penilaian (evaluasi).

SMA Surya Buana Malang merupakan sekolah alam yang berciri khas Islam di Malang. Sekolah ini memiliki progam intensif yaitu penghafalan Al-Qur'an yang menargetkan supaya lulusannya minimal bisa hafal dua juz Al-Qur'an. Selain penghafalan Al-Qur'an berbagai upaya dilakukan agar SMA Surya Buana Malang mampu bersaing dengan sekolah lain. Upaya yang dilakukan yaitu dengan mengadakan progam intensif diluar kurikulum nasional, dimana sekolah menyebutnya dengan hidden kurikulum yang kurikulumnya harus disesuaikan dengan kebudayaan yang ada di sekolah. Ada tiga progam intensif yang diselenggarakan oleh sekolah yaitu tahfidz (hafalan Qur,an), entrepreneur, dan karya tulis ilmiah. Selain progam intensif ada juga progam khusus unggulan sekolah yaitu progam study visual. Study visual ini merupakan progam yang disusun untuk mengintegrasikan beberapa mata pelajaran untuk menyusun satu kegiatan yang mempresentasikan mata pelajaran klasikal ke kehidupan nyata.

Dengan adanya hidden kurikulum yang diluar kurikulum nasional, tentu membuat sekolah harus melakukan tata laksana pengelolaan kurikulum untuk menentukan kurikulum tambahan yang sesuai dengan budaya SMA Surya Buana Malang yang cenderung berbeda dengan sekolah lain pada umumnya. Berdasarkan penjelasan tersebut, maka dilakukan penelitian yang berjudul "Manajemen Kurikulum di Sekolah Alam Berciri Khas Islam”. 


\section{METODE}

Pendekatan yang digunakan dalam penelitian ini adalah kualitatif yang dilakukan bertujuan untuk mendeskripsikan aspek yang menjadi fokus penelitian yang terkait dengan kurikulum terpadu di sekolah alam berciri khas Islam di SMA Surya Buana Malang sedangkan jenis penelitian yang digunakan adalah studi kasus karena penelitian dilakukan pada satu lingkungan saja yaitu di SMA Surya Buana Malang yang bertujuan untuk mengetahui dan menemukan fakta atau peristiwa yang dianggap unik yang tidak terjadi pada sekolah lain baik sekolah negeri, sekolah swasta maupun madrasah. Lokasi penelitian di SMA Surya Buana Malang yang terletak di Jalan Candi VI D 01/06 Karangbesuki Sukun Kota Malang.

Sumber data dalam penelitian ini yaitu kepala sekolah, wakil kepala bagian kurikulum, guru-guru, dan siswa. Data tambahan yang digunakan adalah dokumen yang dianalisis oleh peneliti, diantaranya: kalender sekolah, progam kerja tahunan, jadwal pelajaran, pembagian kerja guru, serta foto-foto kegiatan yang berkaitan dengan fokus penelitian.

Prosedur pengumpulan data yang digunakan peneliti, yaitu: (1) wawancara mendalam dilakukan untuk memperoleh data mengenai penyusunan kurikulum terpadu di SMA Surya Buana Malang; (2) pengamatan atau observasi dilakukan untuk mengamati kegiatan pelaksanaan kurikulum terpadu di SMA Surya Buana Malang; dan (3) Teknik dokumentasi untuk mendukung hasil wawancara dan pengamatan berupa foto atau dokumen mengenai kurikulum terpadu di SMA Surya Buana Malang, teknik ini digunakan untuk memperoleh data sifatnya tertulis maupun tercetak. Proses analisis data yaitu melalui pengumpulan data, reduksi data, penyajian data, dan penarikan kesimpulan. Penelitian ini dilakukan pengecekan keabsahan data dengan menggunakan triangulasi data yaitu sumber data dan teknik, ketekunan pengamatan, dan pengecekan anggota.

\section{HASIL}

\section{Perencanaan Kurikulum Terpadu di SMA Surya Buana Malang}

Perencanaan kurikulum di SMA Surya Buana Malang di awali dengan menentukan visi dan misi sekolah setelah itu diadakan workshop untuk mempersiapkan segala macam perangkat pembelajaran selama satu tahun ajaran. Dalam workshop dibentuk tim khusus untuk membuat kurikulum seperti apa yang harus diterapkan di SMA Surya Buana Malang mengingat perbedaan kurikulum yang diterapkan dibanding sekolah lain pada umumnya.

\section{Pelaksanaan Kurikulum Terpadu di SMA Surya Buana Malang}

Pelaksanaan kurikulum terpadu di SMA Surya Buana mencakup pelaksanaan tentang penyusunan kalender sekolah, penyusunan progam kerja tahunan, penyusunan jadwal pelajaran, pembagian beban kerja guru dan penyusunan progam belajar peserta didik. Berikut peneliti akan memaparkan hasil penelitian poin ke poin mengenai pelaksanaan kurikulum terpadu di SMA Surya Buana Malang.

\section{Penyusunan Kalender Sekolah di SMA Surya Buana Malang}

Penyusunan kalender sekolah di SMA Surya Buana Malang dilakukan setelah mendapat kalender pendidikan nasional. Tidak hanya itu sekolah juga melihat kalender umum atau kalender yang dipakai masyarakat sehari-hari. Kalender pendidikan berperan sebagai alat untuk menentukan awal dan akhir, serta proses kegiatan pembelajaran dalam satu tahun ajaran. Kemudian harus disesuaikan dengan kegiatan pembelajaran yang ada di SMA Surya Buana Malang, mengingat pembelajaran di sekolah alam berbeda dengan sekolah lain pada umumnya.

\section{Penyusunan Progam Kerja Tahunan di SMA Surya Buana Malang}

Penyusunan progam kerja dilakukan setiap akhir tahun ajaran baru dan sekolah melakukan evaluasi di setiap akhir tahun untuk menentukan progam kerja baru selanjutnya. Peran kepala sekolah menjadi sangat penting dalam penyusunan progam kerja tahunan ini, karena kepala sekolah harus memberikan arahan yang baik kepada wakil kepala sekolah dan guru yang terlibat agar bisa menyesuaikan ide dari 
kepala sekolah agar bisa dilaksanakan.

\section{Penyusunan Jadwal Pelajaran Untuk Seluruh Peserta Didik di SMA Surya Buana Malang}

Penyusunan jadwal pelajaran disusun oleh wakil kepala sekolah bagian kurikulum beserta tim kurikulum dengan melihat urgensi kompetensi mata pelajaran yang kemudian dikonsultasikan kepada kepala sekolah. Pembagian tugas dilakukan dengan membuat tim khusus, yang kemudian membagi jadwal pelajaran yang memerlukan konsentrasi tinggi ditempatkan di pagi hari.

\section{Pembagian Beban Kerja Guru di SMA Surya Buana Malang}

Pembagian beban mengajar berdasarkan pada banyaknya guru dan jumlah jam mengajar guru. Guru diharuskan mengajar minimal selama 24 jam dalam seminggu. Pembagian juga dilakukan berdasarkan jumlah rombongan belajar yang ada. Semakin banyak rombongan belajar, semakin banyak pula jam mengajar. Peran kepala sekolah juga menjadi sangat penting dikarenakan kepala sekolah menjadi supervisor dan fasilitator dalam pembagian beban kerja guru di SMA Surya Buana Malang. Kendala yang muncul sudah dapat diselesaikan dengan baik oleh pihak sekolah. pembagian beban mengajar guru sudah berjalan efektif di SMA Surya Buana Malang.

\section{Penyusunan Progam Belajar Mengajar di SMA Surya Buana Malang}

Hasil penelitian menunjukan bahwa penyusunan progam belajar mengajar dilakukan workshop untuk mempersiapkan bapak/ibu guru mulai dari perangkat sampai administratif dalam mengajar, serta rapat kerja itu untuk progam kerja sekolah. Diworkshop pertama membahas terkait dengan kalender pendidikan, yang diterbitkan dinas pendidikan. Selanjutnya guru melihat struktur kurikulum dimasingmasing pelajaran, kemudian dari struktur pembelajaran itu dan dari beban materi pelajaran di masingmasing mata pelajaran guru menyusun silabus, prota, promes kemudian RPP. Adapun kriteria yang dibuat khusus yaitu progam belajar mengajar harus lebih mengutamakan mata pelajaran yang ada di ujian nasional, kemudian life skill, pembekalan bagaimana peserta mempunyai kesadaran belajar dalam berwirausaha, serta mengembangkan pashion minat dan bakat

\section{Evaluasi Kurikulum Terpadu di SMA Surya Buana Malang}

Evaluasi dilaksanakan melalui beberapa tahapan yaitu, rapat mingguan biasa dilakukan pada hari jum'at sebelum memulai rapat guru membaca Al-Qur'an. Pada rapat mingguan ini guru melakukan evaluasi mengenai progam yang sudah berjalan selama satu minggu itu. Semua guru yang menjadi koordinator dalam progam akan menyampaiakan evaluasi progam mereka selanjutnya, jika ada kendala dalam pelaksanaan progam maka guru akan menyebutkannya lalu mencari solusi untuk memecahkan masalah tersebut, sehingga untuk kegiatan selanjutnya kendala yang terjadi sudah tidak menjadi hambatan lagi. Selain itu ada rapat harian dan rapat awal dan akhir semester yang mencakup keseluruhan evaluasi progam selama satu tahun ajaran. Untuk mengetahui keseluruhan proses manajemen dapat di ilustrasikan pada gambar 1.

Pada Gambar 1 dijelaskan hasil temuan seluruh rangkaian penyusunan kurikulum terpadu yang ada di SMA Surya Buana Malang.

\section{PEMBAHASAN}

\section{Perencanaan Kurikulum Terpadu di SMA Surya Buana Malang}

Perencanaan kurikulum terpadu di SMA Surya Buana Malang diawali dengan menentukan visi dan misi sekolah. Setelah visi dan misi sekolah disetujui selanjutnya diadakan workshop untuk mempersiapkan segala macam perangkat pembelajaran selama satu tahun ajaran. Dalam workshop dibentuk tim khusus untuk membuat kurikulum seperti apa yang harus diterapkan di SMA Surya Buana Malang mengingat perbedaan muatan lokal yang diterapkan dibanding sekolah lain pada umumnya sehingga peserta didik dapat mudah dalam belajar dan memperoleh ilmu serta dapat meningkatkan kemampuan peserta didik baik dari nilai atau sikap dan tingkah laku peserta didik. Menurut hasil penelitian oleh Yusnaini (2014:16) menjelaskan "perencanaan kurikulum dilakukan dengan menyusun dokumen KTSP yang 
berkaitan dengan profil sekolah, penetapan visi misi dan tujuan sekolah, penetapan program sekolah dan struktur kurikulum, beban belajar, pendidikan kecakapan hidup, pendidikan berbasis keunggulan lokal dan keunggulan global, penilaian, kenaikan kelas, kelulusan dan beberapa aturan sekolah lainnya".

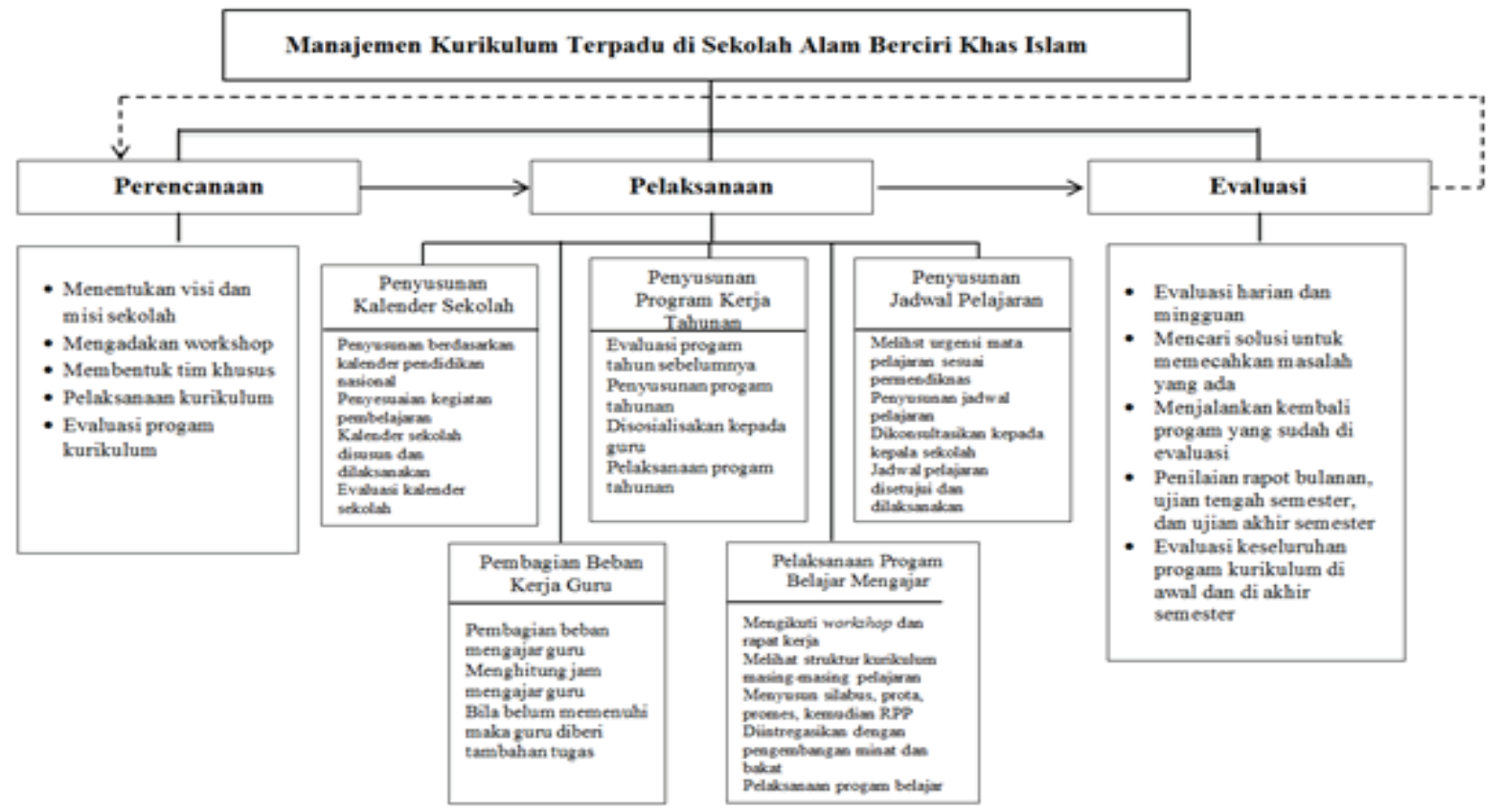

Gambar 1 Skema Manajemen Kurikulum Terpadu di SMA Surya Buana Malang

Kurikulum yang diterapkan disekolah memakai kurikulum 2013, dikarenakan kurikulum 2013 merupakan kurikulum nasional saat ini dan hidden curriculum yang merupakan kurikulum khusus SMA Surya Buana Malang. Menurut penelitian Ainurrosidah (2018:164) kurikulum terpadu merupakan "perpaduan antara kurikulum yang ditetapkan oleh Dinas Pendidikan Nasional (Diknas), kurikulum yang berasal dari Kementrian Agama (Kemenag) dan kurikulum diniyah ciri khas dari sekolah itu sendiri.

Berdasarkan hasil temuan di atas dapat disimpulkan bahwa dalam perencanaan kurikulum di SMA Surya Buana Malang adalah dengan mengutamakan peserta didik agar dapat menerima ilmu dengan sebaik mungkin, mengingat pembelajaran yang dipelajari di sekolah alam berciri khas Islam berbeda dengan sekolah umum lainnya terutama di bidang life skill dan agama.

\section{Penyusunan Kalender Pendidikan di SMA Surya Buana Malang}

Hasil penelitian menunjukan bahwa penyusunan kalender sekolah merupakan pengaturan waktu kegiatan pembelajaran peserta didik selama satu tahun ajaran yang mencakup awal tahun pelajaran, minggu efektif belajar, waktu pembelajaran efektif, dan hari libur. Oleh karena itu keberadaan kalender pendidikan sangat berperan penting untuk keefektifan kegiatan pembelajaran di sekolah khususnya di SMA Surya Buana Malang. Penyusunan kalender sekolah di SMA Surya Buana Malang dilakukan setelah mendapat kalender pendidikan nasional dari pusat.

Hasil penelitian diatas didukung oleh penelitian Qoriah (2018:189) yang menjelaskan bahwa "kalender akademik mencakup permulaan tahun pelajaran, minggu efektif belajar, waktu pembelajaran efektif, hari libur hari-hari fakultatif'. Kalender sekolah merupakan salah satu komponen yang memiliki peran penting dalam upaya mengoptimalkan kegiatan belajar mengajar yang terjadi antara pendidik dan peserta didik.

Berdasarkan temuan dan hasil penelitian dari peneliti lain maka dapat disimpulkan bahwa kalender sekolah merupakan kegiatan yang mempunyai peran penting dalam mengoptimalkan kegiatan belajar mengajar dan proses pengelompokan jumlah hari efektif dan hari libur dalam satu tahun ajaran serta pada proses perencanaan hingga penyusunannya dengan mempertimbangkan hal-hal tertentu yang dapat menjadi penghambat selama kegiatan belajar mengajar agar dapat dijadikan patokan pada suatu 
lembaga pendidikan.

\section{Penyusunan Progam Kerja Tahunan di SMA Surya Buana Malang}

Hasil penelitian menunjukan bahwa progam kerja tahunan dibuat oleh semua perangkat sekolah mulai dari kepala sekolah wakil kepala sekolah beserta guru. Penyusunan progam kerja tahunan dilakukan pada akhir tahun ajaran baru dengan melakukan evaluasi tahun ajaran yang sudah terlaksana dan yang akan di konsep untuk digunakan pada tahun ajaran baru yang di arahkan oleh kepala sekolah untuk membantu mengembangkan potensi sekolah dan peserta didik. progam kerja tahunan bertujuan untuk memudahkan pengawasan kegiatan pembelajaran yang ada di sekolah.

Hasil penelitian di atas didukung oleh teori yang dikemukakan oleh Soetopo (2004:26) bahwa "progam tahunan bertujuan untuk memudahkan cara kerja yang teratur dan berencana, serta memudahkan penilaian dan pengawasan".

Berdasarkan temuan dan teori dapat disimpulkan bahwa penyusunan progam tahunan merupakan progam yang disusun oleh semua unsur sekolah yang bertujuan untuk memudahkan dalam menilai peserta didik dan menjadi bahan acuan untuk langkah-langkah yang akan diambil berikutnya.

\section{Penyusunan Jadwal Pelajaran Untuk Seluruh Peserta Didik di SMA Surya Buana Malang}

Hasil penelitian menjelaskan bahwa penyusunan jadwal pelajaran disusun oleh wakil kepala sekolah bagian kurikulum beserta tim khusus kurikulum. Tahap-tahap yang dilakukan adalah Pertama dirapatkan dulu urgensi kompetensi, kemudian mata pelajaran mana yang perlu jam tambahan tentu tetap mengacu pada ketentuan yang disebutkan di permendiknas. Kemudian dikonsultasikan kepada kepala sekolah setelah dievaluasi dan disetujui oleh kepala sekolah jadwal pelajaran siap untuk dilaksanakan. Adapun kriteria khusus yang dibuat yaitu jadwal pelajaran yang memerlukan konsentrasi tinggi ditempatkan di pagi hari.

Hasil penelitian tersebut didukung oleh teori yang dikemukakan Soetopo (2004:30) bahwa tahap yang diperlukan dalam penyusunan jadwal pelajaran yaitu "tahap pendahuluan/inventarisasi mata pelajaran, jumlah tiap mata pelajaran, guru yang mengampu, dan jumlah jam mengajar tiap guru, jumlah kelas". Tahapan ini dilakukan agar beban mengajar gru sesuai dengan ketentuan yang ada dan menghindari terjadinya tebrakan jadwal pelajaran.

Berdasarkan temuan dan teori di atas dapat disimpulkan bahwa penyusunan jadwal pelajaran dilakukan oleh wakil kepala sekolah bagian kurikulum dan tim khusus bagian kurikulum yang menetapkan pembagian jadwal pelajaran dengan persetujuan dari kepala sekolah. Hal tersebut bertujuan agar jadwal pelajaran bisa dilaksanakan dengan baik sesuai ketentuan dan tidak terjadi tabrakan jadwal pelajaran.

\section{Pembagian Beban Kerja Guru di SMA Surya Buana Malang}

Hasil penelitian menunjukan bahwa pembagian beban kerja guru berdasarkan pada banyaknya guru dan jumlah jam mengajar guru. Guru diharuskan mengajar selama 24 jam dalam satu minggu. Sedangkan penelitian yang dilakukan Arysandi (2015) menyebutkan bahwa "guru pegawai negeri sipil diharuskan mengajar minimal selama 24 jam dan maksimal selama 40 jam Pembagian juga dilakukan berdasarkan jumlah rombongan belajar yang ada". Semakin banyak rombongan belajar, semakin banyak pula jam mengajar. Peran kepala sekolah menjadi sangat pentin dikarenakan kepala sekolah menjadi supervisor dan fasilitator dalam pembagian beban mengajar guru di SMA Surya Buana Malang.

Berdasarkan temuan di atas dapat disimpulkan bahwa pembagian beban mengajar guru merupakan sebuah alat untuk menghitung keefektifan guru dalam mengajar dilihat dari jam mengajar yang dilakukan oleh guru tersebut. Pengaturan jam mengajar yang baik akan berdampak pada pengajaran yang efektif dan efisien, begitu juga sebaliknya.

\section{Penyusunan Progam Belajar Mengajar di SMA Surya Buana Malang}

Hasil penelitian menunjukan bahwa pelaksanaan progam belajar mengajar dilakukan workshop untuk mempersiapkan bapak/ibu guru mulai dari perangkat sampai administratif dalam mengajar, serta 
rapat kerja itu untuk progam kerja sekolah. Diworkshop pertama membahas terkait dengan kalender pendidikan, yang diterbitkan dinas pendidikan. Selanjutnya guru melihat struktur kurikulum dimasingmasing pelajaran, kemudian dari struktur pembelajaran itu dan dari beban materi pelajaran di masingmasing mata pelajaran guru menyusun silabus, prota, promes kemudian RPP. Sejalan dengan hal tersebut dari hasil penelitian Sutikno (2009:208), menjelaskan "guru-guru melaksanakan proses belajar mengajar dengan berpedoman pada silabus, kalender pendidikan, RPP, program semester yang telah disusun sebelumnya".Adapun kriteria yang dibuat khusus yaitu progam belajar mengajar harus lebih mengutamakan mata pelajaran yang ada di ujian nasional, kemudian life skill, pembekalan bagaimana peserta mempunyai kesadaran belajar dalam berwirausaha, serta mengembangkan pashion minat dan bakat.

Temuan peneliti tersebut didukung oleh teori yang dikemukakan oleh Soetopo (2004:30) menemukan bahwa, dalam rangka menyusun progam pengajaran tahunan dan semesteran, seorang guru perlu melakukan kegiatan-kegiatan sebagai berikut: 1)Mempelajari secara umum/garis besar tentang susunan progam; 2) Mempelajari kalender pendidikan/sekolah; 3) Memperhatikan alokasi waktu yang ada terhadap mata pelajaran yang bersangkutan setiap semester; 4) Menganalisis pokok bahasan/konsep/ tema/bahan kajian yang ada dalam pengaturan mata pelajaran yang bersangkutan; 5) Memperhatikan jadwal pelajaran; 5) Menyusun progam pengajaran tahunan dan semsester, dengan menggunakan format tertentu.

Berdasarkan temuan dan teori diatas dapat disimpulkan bahwa dalam pelaksanaan progam belajar harus melihat hal-hal yang secara langsung dapat berpengaruh terhadap proses pembelajaran yang dimulai dari adanya progam tahunan sekolah, kalender sekolah, alokasi waktu pelajaran yang ada dan jadwal pelajaran. Disamping itu juga harus memerlukan pelatihan atau workshop dalam pembuatan progam belajar mengajar yang bertujuan untuk mematangkan konsep yang sudah dimiliki oleh para guru.

\section{Evaluasi Kurikulum Terpadu di SMA Surya Buana Malan}

Hasil penelitian menunjukan bahwa valuasi kurikulum di SMA Surya Buana dilakukan setiap hari dan dalam rapat mingguan biasa dilakukan pada hari jum'at sebelum memulai rapat guru membaca Al-Qur'an. Pada rapat mingguan ini guru melakukan evaluasi mengenai progam yang sudah berjalan selama satu minggu itu. Semua guru yang menjadi koordinator dalam progam akan menyampaiakan evaluasi progam mereka selanjutnya, jika ada kendala dalam pelaksanaan progam maka guru akan menyebutkannya lalu mencari solusi untuk memecahkan masalah tersebut, sehingga untuk kegiatan selanjutnya kendala yang terjadi sudah tidak menjadi hambatan lagi. Menurut hasil penelitian Nugroho (2014:189) evaluasi kurikulum dilakukan sekolah dengan melibatkan kepala sekolah, waka kurikulum, dan pendidik setiap akhir tahun pelajaran. Mulai dari pembelajaran, materi, modul, penilaian, sampai halhal teknisnya semuanya dievaluasi. Evaluasi penilaian peserta didik berfungsi sebagai alat untuk mengukur tingkat pengetahuan peserta didik baik berupa teori akademik maupun perilaku peserta didik yang dilakukan dengan pengamatan saat mengajar, ulangan harian, ujian tengah semester, dan ujian akhir semester. Penilaian peserta didik di SMA Surya Buana Malang sama halnya dengan penilaian pada sekolah pada umum lainnya. Penilaian meliputi aspek kognitif, afektif dan psikomotorik. Menurut hasil penelitian Ningrum (2015:417) menjelaskan "penilaian yang dilakukan guru untuk mengisi rapor dilihat dari penilaian portofolio, rubrik penilaian, penilaian diri sendiri, dan juga dilihat dari ulangan harian atau tugas yang telah diberikan oleh guru. SKL Kurikulum 2013 berisi mengenai sikap, pengetahuan, dan keterampilan peserta didik. Namun penilaian di SMA Surya Buana perbedaan terletak pada penilaian disetiap semester dimana para peserta didik dites kemampuan dalam menghafal Al-Qur'an. Kriteria khusus juga diberikan oleh kepala sekolah bagi peserta didik yang mempunyai kemampuan lebih. Untuk bentuk penilaian diserahkan kepada guru untuk memberikan nilai kepada peserta didik dan kepala sekolah sebagai supervisor.

Hasil penelitian diatas didukung oleh teori yang dikemukakan oleh Triwiyanto (2014:104) "penilaian hasil belajar oleh pendidik dilakukan secara berkesinambungan, bertujuan untuk memantau proses, kemajuan belajar peserta didik, dan untuk meningkatkan efektivitas kegiatan pembelajaran". 
Berdasarkan temuan dan teori tersebut dapat disimpulkan bahwa penilaian pembelajaran peserta didik merupakan alat untuk mengukur tingkat pengetahuan peserta didik baik berupa teori, praktek dan sebagai alat pengambilan keputusan. Adapun beberapa hal yang harus dipertimbangkan dalam memberikan penilaian yakni meliputi aspek kognitif, afektif dan psikomotorik. Hal yang membedakan di SMA Surya Buana Malang dibanding dengan sekolah umum lainnya adalah disetiap semester para peserta didik dites kemampuan dalam menghafal Al-Qur'an.

\section{KESIMPULAN}

\section{Perencanaan Kurikulum Terpadu}

Perencanaan kurikulum terpadu diawali dengan menentukan visi dan misi sekolah. Setelah visi dan misi sekolah disetujui selanjutnya diadakan workshop untuk mempersiapkan segala macam perangkat pembelajaran selama satu tahun ajaran. Dalam workshop dibentuk tim khusus untuk membuat kurikulum seperti apa yang harus diterapkan di sekolah mengingat perbedaan muatan lokal yang diterapkan dibanding sekolah lain pada umumnya sehingga peserta didik dapat mudah dalam belajar dan memperoleh ilmu serta dapat meningkatkan kemampuan peserta didik baik dari nilai atau sikap dan tingkah laku peserta didik. Kurikulum yang diterapkan disekolah memakai kurikulum 2013, dikarenakan kurikulum 2013 merupakan kurikulum nasional saat ini. Oleh karena itu perencanaan kurikulum terpadu harus mengutamakan peserta didik agar dapat menerima ilmu dengan sebaik mungkin, mengingat pembelajaran yang dipelajari di sekolah alam berciri khas Islam berbeda dengan sekolah umum lainnya terutama di bidang life skill dan agama.

\section{Penyusunan Kalender Pendidikan}

Penyusunan kalender sekolah merupakan pengaturan waktu kegiatan pembelajaran peserta didik selama satu tahun ajaran yang mencakup awal tahun pelajaran, minggu efektif belajar, waktu pembelajaran efektif, dan hari libur. Oleh karena itu keberadaan kalender pendidikan sangat berperan penting untuk keefektifan kegiatan pembelajaran di. Penyusunan kalender sekolah dilakukan setelah mendapat kalender pendidikan nasional dari pusat.

\section{Penyusunan Progam Kerja Tahunan}

Progam kerja tahunan dibuat oleh semua perangkat sekolah mulai dari kepala sekolah wakil kepala sekolah beserta guru. Penyusunan progam kerja tahunan dilakukan pada akhir tahun ajaran baru dengan melakukan evaluasi tahun ajaran yang sudah terlaksana dan yang akan di konsep untuk digunakan pada tahun ajaran baru yang di arahkan oleh kepala sekolah untuk membantu mengembangkan potensi sekolah dan peserta didik. progam kerja tahunan bertujuan untuk memudahkan pengawasan kegiatan pembelajaran yang ada di sekolah.

\section{Penyusunan Jadwal Pelajaran Untuk Seluruh Peserta Didik}

Penyusunan jadwal pelajaran disusun oleh wakil kepala sekolah bagian kurikulum beserta tim khusus kurikulum. Tahap-tahap yang dilakukan adalah Pertama dirapatkan dulu urgensi kompetensi, kemudian mata pelajaran mana yang perlu jam tambahan tentu tetap mengacu pada ketentuan yang disebutkan di permendiknas. Kemudian dikonsultasikan kepada kepala sekolah. Adapun kriteria khusus yang dibuat yaitu jadwal pelajaran yang memerlukan konsentrasi tinggi ditempatkan di pagi hari.

\section{Pembagian Beban Kerja Guru}

Pembagian beban kerja guru berdasarkan pada banyaknya guru dan jumlah jam mengajar guru. Guru diharuskan mengajar selama 24 jam dalam satu minggu. Pembagian juga dilakukan berdasarkan jumlah rombongan belajar yang ada. Semakin banyak rombongan belajar, semakin banyak pula jam mengajar. Peran kepala sekolah menjadi sangat penting dikarenakan kepala sekolah menjadi supervisor dan fasilitator dalam pembagian beban mengajar guru di sekolah.

\section{Pelaksanaan Progam Belajar Mengajar}

Pelakasanaan progam belajar mengajar dilakukan workshop untuk mempersiapkan bapak/ibu guru mulai dari perangkat sampai administratif dalam mengajar, serta rapat kerja itu untuk progam 
kerja sekolah. Diworkshop pertama membahas terkait dengan kalender pendidikan, yang diterbitkan dinas pendidikan. Selanjutnya guru melihat struktur kurikulum dimasing-masing pelajaran, kemudian dari struktur pembelajaran itu dan dari beban materi pelajaran di masing-masing mata pelajaran guru menyusun silabus, prota, promes kemudian RPP. Adapun kriteria yang dibuat khusus yaitu progam belajar mengajar harus lebih mengutamakan mata pelajaran yang ada di ujian nasional, kemudian life skill, pembekalan bagaimana peserta mempunyai kesadaran belajar dalam berwirausaha, serta mengembangkan passion minat dan bakat.

\section{Evaluasi Kurikulum Terpadu}

Hasil penelitian menunjukan bahwa evaluasi progam kurikulum terpadu dilaksanakan setiap minggu untuk progam keseluruhan evaluasi kurikulum dilakukan pada awal dan akhir semester selain itu evaluasi melalui penilaian peserta didik berfungsi sebagai alat untuk mengukur tingkat pengetahuan peserta didik baik berupa teori akademik maupun perilaku peserta didik yang dilakukan dengan pengamatan saat mengajar, ulangan harian, ujian tengah semester, dan ujian akhir semester. Penilaian meliputi aspek kognitif, afektif dan psikomotorik. Namun bedanya adalah disetiap semester para peserta didik dites kemampuan dalam menghafal Al-Qur'an. Kriteria khusus juga diberikan oleh kepala sekolah bagi peserta didik yang mempunyai kemampuan lebih. Untuk bentuk penilaian diserahkan kepada guru untuk memberikan nilai kepada peserta didik dan kepala sekolah sebagai supervisor.

\section{DAFTAR RUJUKAN}

Ainurrosidah, L. Ulfatin, N. \& Wiyono, B.B. 2018. Pembentukan Karakter Peserta Didik Pada Sekolah Berbasis Pesantren Melalui Implementasi Kurikulum Terpadu. Jurnal Administrasi dan Manajemen Pendidikan, 1(2), $160-170$.

Dakir. 2004. Perencanaan dan Pengembangan Kurikulum. Jakarta: Rineka Cipta

Miles, M. B, Huberman,A.M, dan Saldana,J. 2014. Qualitative Data Analysis, A Methods Sourcebook, Edition 3. USA: Sage Publications. Terjemahan Tjetjep Rohindi Rohidi, UI-Press

Ningrum, E.S. \& Sobri. A.Y. 2015. Implementasi Kurikulum 2013 di Sekolah Dasar. Jurnal Manajemen Pendidikan, 24(5), 416-423.

Nugroho. A. W., Sobri. A. Y, \& Triwiyanto. T. 2014. Manajemen Kurikulum Uni-Bridge di Sekolah Menengah Atas Katolik. Jurnal Manajemen Pendidikan, 24 (3), 186-192.

Qoriah, U.M., Bafadal. I, \& Mustiningsih. 2018. Manajemen Implementasi Kurikulum dan Pembelajaran Berbasis Tauhid dalam Pembentukan Karakter Peserta Didik. Jurnal Administrasi dan Manajemen Pendidikan, 1(2), 188-197.

Slameto, 2003. Belajar dan Faktor-Faktor Yang Mempengaruhinya. Jakarta: PT. Rineka Cipta.

Sugiyono. 2013. Memahami Penelitian Kualitatif. Bandung: Alfabeta.

Sutikno. 2009. Implementasi Kurikulum 2006 di Sekolah Dasar (Studi Multisitus di SDN Bintoro 4 dan SDN Guntur 1 Kabupaten Demak. Tesis tidak diterbitkan. Malang: PPs UM.

Undang-Undang Republik Indonesia Nomor 20 Tahun 2003 tentang Sistem Pendidikan Nasional. 2012. Bandung: Citra Umbara

Yusnaini, Usman, N, \& Ibrahim, S. 2014. Evaluasi Kurikulum Tingkat Satuan Pendidikan Pada Sekolah Dasar Negeri 67 Kota Banda Aceh. Jurnal AdministrasiPendidikan Pascasarjana Universitas Syariah Kuala. 2 (1), 13-24. 